In Search of a New Bretton Woods: Reserve Currencies and Global Imbalances

Florence, Italy, October 20, 2006

January 4, 2007

\title{
Understanding the Old and New Bretton Woods
}

\author{
Paul Wachtel \\ Professor of Economics \\ Stern School of Business \\ New York University \\ 44 West $4^{\text {th }}$ Street \\ New York, NY 10012 USA \\ pwachtel@stern.nyu.edu
}

\begin{abstract}
There are two interrelated usages of the term Bretton Woods in international macroeconomics. First it refers to the institutional structure put in place to govern international financial relationships in the post World War II era. Second it refers to the way in which the financial interactions relationships among countries operate. In both instances there are important differences between the Bretton Woods of the early post war period and the contemporary experience. In particular, the most important Bretton Woods institution, the IMF, plays a different role today than it did in the original fixed exchange rate system of the post war period. With regard to operations, large US current account deficits in recent years provide some resemblance to the role of the dollar earlier. This paper explains and contrasts the old and new Bretton Woods institutional and operating systems.
\end{abstract}

Key words: Bretton Woods, exchange rate regimes, IMF, current account

JEL classifications codes: F33, F32 
Bretton Woods is a beautiful place in the White Mountains of New Hampshire. But, it is also a key phrase in the lexicon of international macroeconomics. The term Bretton Woods figures prominently in economic thinking and the search for a new Bretton Woods (hereinafter, BW) goes on far from the New Hampshire mountains. As the term has become increasingly familiar, it has become less clear what the phrase is supposed to convey.

The BW system that emerged from that mountain setting has two distinct but related parts. First, it refers to the institutional structure put in place to govern international economic relations and second, it refers to the way in which international financial relationships operate. Thus, the original system (old BW) consists of the institutions and operations of international finance from the end of the war to the breakdown of fixed exchange rates in the early 1970s. The old BW system had a long demise - from the end of gold convertibility in 1971 through the financial crises of the 1990s. However, there is now much conjecture about the emergence of a new BW system.

Our objective here is to examine old BW and to provide a context for understanding the new BW. Just as old BW has two facets - institutions and operations - so does new BW. In the aftermath of the financial crises of the 1990s there were wide discussions of the reform of the BW institutions, particularly the IMF, and the search for a new financial architecture continues to this day. From the operational perspective, the influential work in just the last few years by Dooley, Folkerts-Landau and Garber (DFG) postulates that the world is operating under a new BW system. DFG argue that the international financial system operates today with features that closely resemble the old BW system.

We will find that the old BW system was remarkable in many respects. First, the wartime conference cobbled together a set of institutions and arrangements for international financial relationships that were just the right thing for the right time. The aim was to provide a setting for post war economic growth and to avoid the problems that hobbled the interwar economy. The old BW system met these objectives handsomely. 
However, the old BW system was a victim of its own success. A growing world economy evolved away from the initial conditions of the post war period. The growth of trade increased the demand for reserve assets, which were beyond the supply capability of the old BW system. Furthermore, the re-globalization of a growing world economy inevitably led to more open capital accounts.

With regard to institutional changes, no suggested reform has the consensus backing that led to the old BW. With regard to operational changes, DFG postulate that the international financial system has been operating in ways that bear many similarities to old BW. Their view is that this new BW can be sustained for a generation or just like old BW worked for the first post war generation. However, their view is debated by observers who view the large global imbalances of countries like China and the US as unsustainable.

Our examination of the institutions and operations of the old BW era will, hopefully, help us understand the two facets of the new BW era. The paper starts with a step back in history to the Bretton Woods conference that brought together 730 policy makers from 45 countries in the midst of the Second World War. It was an odd gathering in an odd place that, even more oddly, had enormous influence.

Bretton Woods, 1944. There was a consensus among the allies that an important part of victory - the success of the post war world - would be new arrangements in international economic relationships. Efforts to develop a new structure for international financial relationships started early in the War and culminated in the BW conference held over three weeks in July 1944. The conference started just a month after D-Day when there was a thought or a hope that the war would end soon. So, with the war waning and with a broad determination to change the landscape of international economics, hundreds of participants converged on a very remote resort hotel sitting at the foot of the tallest mountain in the Northeastern US. Most participants arrived by special overnight trains from Washington and from Atlantic City where key participants had hammered out the final plans. In fact, discussion had been underway for several years between the two key players - the US and the UK. The agreements were virtually in place before everyone reached New Hampshire. 
There were really two players at BW - John Maynard Keynes of the UK and a less well known Treasury economist from the US, Harry Dexter White. Keynes and White had been discussing the design a post war international financial architecture for several years and the Keynes and White plans were made public early in 1942. Much debate went on - often with coded trans Atlantic messages - before the meeting at BW started. One thing is for sure, there was a determination to change the way the world economy was managed in the post war world.

Sixty years later, there is still determination to manage and stabilize international financial relations but there is less and less agreement about how to do so. Perhaps the Bretton Woods conference was successful because of Keynes' dominant intellect or because the US had already emerged as the predominant player on the post war world stage. The willingness to reach agreement stands in sharp contrast with recent experiences such as the failures of the Doha trade talks or the attempts to reform the IMF since the financial crises of the 1990s.

BW in 1944 was different because there was a shared perception that there was something terribly wrong with the prewar structure and that an entirely new system was needed. Bretton Woods was different because of the shared fear of returning to the conditions and structure of the interwar period. International trade plummeted in the Depression particularly as countries competed vigorously to impose trade restrictions on each other in vain efforts to save domestic industries. The determination to avoid a return to such a situation was accentuated by the fact that all serious economists expected that there would be sharp post-war economic slowdown. ${ }^{1}$ The difficulty in establishing trade policies was probably understood at BW. Moreover, it was known that the pre-war tariff wars were misguided response to financial crises. Thus, the emphasis at BW was the efforts to reconstruct the financial system.

Financial architecture before BW. In theory the countries of the pre war world were on the gold standard. Now, the gold standard model - David Hume's price-specieflow model - is elegant and simple. Countries with trade deficits have to export gold,

\footnotetext{
${ }^{1}$ It is interesting to note that the one failure of BW was dealing directly with the trade issue. The conference envisioned that in addition to the international financial institutions there would be a comprehensive organization to govern trade. Such an organization did not emerge and the GATT agreements of 1947 were a weak substitute from the very start.
} 
which leads to a domestic money contraction, prices fall and presto the deficit disappears. It was probably the first general equilibrium model and is much loved by economists.

Although, the gold standard model called for automatic self correcting responses to imbalances, the ability of central banks, then as now, to influence interest rates and credit (money supply) expansion complicated the structure. The gold standard model demanded that central bankers play by the "rules of the game" (a term coined by Keynes in the 20s). The unwritten rules stated that a proper central bank set policy that was consistent with the automatic adjustment mechanism of the gold standard. Playing the game meant that a central bank would raise interest rates and contracts the money supply in the presence of incipient gold losses. Thus, the system can work without major gold reserves or gold flows. However, by the time the term was coined, central banks were flouting the rules; other things, domestic concerns, had a substantial influence on interest rate and credit policy (which at that time consisted of discounting by central banks).

Moreover, the gold standard adjustment model abstracts from the existence of international capital markets, which had been around throughout the gold standard era. Lending can stem the demand for gold outflows and thus postpone the operation of the adjustment mechanism. That sounds fine; capital markets can absorb short term shocks without either gold flows or deflation. However, loans accumulate to form a stock of claims on the gold reserves. If reserves are small relative to the accumulated imbalances financed, capital markets can make the system more volatile rather than less volatile.

Capital flows in the late $19^{\text {th }}$ century were often immense. Current account deficits of 10 percent of GDP in developing economies were not unusual. Gold still had some importance; when the willingness to lend dissipated for whatever reason, it was important to have gold reserves to smooth out any adjustments and to set a correction in motion via the money supply. Thus, the world supply of gold provided liquidity to the international financial system. But even in the era where the gold standard supposedly reigned, imbalances could accumulate.

There were multiple pressures on the adjustment mechanism. First, central bank failure to tighten in the presence of a balance of payments deficit could lead to larger and larger deficits. Second, capital market lending could create stock of debt problems that were much larger than the flow imbalance. Third, irregular gold discoveries could lead to 
sudden and disruptive changes in supply and prices. Fourth, there was no natural means of increasing the supply of liquidity as the world economy expanded. Fifth, there was nothing to insure that the gold supply would be in the right place at the right time. A country with a large deficit which capital markets were unable or unwilling to finance would likely not have ample gold reserves as well. If the gold reserves were there, the capital markets would have been willing to lend.

As a consequence some observers contend that the gold standard adjustment mechanism never existed, at least not in the $20^{\text {th }}$ century. That might be an exaggeration but it is true that the $19^{\text {th }}$ century ideal of a self adjusting mechanism through business cycles was no longer operational. In practice, the gold standard was a system of fixed exchange rates where gold served as the liquid reserve asset. And therein lays the problem: the pre war fixed exchange rate system had all the problems we associate with late $20^{\text {th }}$ century fixed exchange rate regimes. The success of the gold standard - i.e. the commitment to and confidence in the fixed exchange rate to gold - was the source of its demise. It allowed imbalances to accumulate to unsustainable levels before any adjustments took place.

The Bretton Woods Solution - Structure. Like the gold standard that preceded it, the old BW structure started with a commitment to fixed exchange rates that would provide a stable environment for the growth of world trade. However, the BW system understood that occasional realignments would be needed so a mechanism for changes in parities was part of the system. In addition, there was an understanding that a growing world economy would need more than just a given supply of gold as a source of liquidity if economies were going to avoid costly deflation episodes. So, a mechanism was needed that could create sufficient liquidity and also make sure that it was in the right place.

The Keynes plan was the more radical suggestion. He proposed an international clearing currency, the 'bancor,' that would be issued by an international clearing union. Importantly, the union could create bancor money by fiat and set its value with respect to gold. Exchange rates to the bancor would be fixed although the clearing union could approve changes. Nations could borrow or just accumulate deficits (overdrafts) or surpluses at the clearing union. The clearing union would be an international central bank, a lender of last resort. 
The plan overlooked the fact that central banking is more than just the ability to create money. The role of central banks is to maintain the stability of the financial system and oversight of money creation is only part of its role. ${ }^{2}$ A successful central bank that maintains stability creates a situation where the lender of last resort facility is rarely called upon. Keynes' clearing union might be a lender of last resort with infinite ability to create money but the plan did not provide it with the political power to influence national economic policies and make sure that countries would not need to resort to borrowing in extremis.

The role of a modern central bank is as much to provide the regulatory and risk management framework that makes the lender of last resort superfluous than it is to be a liquidity facility. With active money markets for interbank lending and refinancing banks can avoid liquidity crises. Good regulation includes, at the extreme, the ability to force banks to change their behavior or even to close banks down before there is any need for the LLR function. Our modern understanding of the lender of last resort is that the lender (the central bank) has to also create a situation where there is rarely any need for its lending services. An analogy can be drawn to the international LLR envisioned by Keynes. To be an effective issuer of bancors, the world lender of last resort would also have to have extensive political and economic powers that seemed as remote at the time of BW as they are now.

We cannot very well expect the international central bank to be able to close down a country; they are all 'too big to fail' or even to put into receivership. Nor did the Keynes plan include a surrender of sovereignty that would enable the international central bank to determine fiscal or monetary policy in a country. A generation later, Geithner (2004) made the same observation in regard to the IMF that has a "financial mission that had some of the characteristics of a lender of last resort...but without mechanisms to constrain risk-taking behavior.”

The plan that won the day at the BW conference was that contributed by the Americans. It shared the same goals - to stabilize exchange rates, facilitate payments,

\footnotetext{
${ }^{2}$ The original theory of central banking - Bagehot - emphasized bank stability. Macroeconomic monetary policy concerns would only appear later. However, in the $20^{\text {th }}$ century central banking became almost exclusively associated with interest rate and money growth policies. The pendulum has begun to swing back with less emphasis on macroeconomic policy and more emphasis on financial sector stability issues.
} 
and encourage investment and trade - but its liquidity feature was less ambitious. An international organization would not have rights to create fiat money but would have lending capabilities that came from member subscriptions. The BW solution provided limited availability of new liquidity and attempted to structure a system that would discourage the demand for it. ${ }^{3}$

The differences between the Keynes and White plans do not seem large but they do represent different views of the world. In the view of de Vries (1986) Keynes advocated a highly structured system with rules governing trade and payments and intergovernmental cooperation to manage the system. The White plan gave more emphasis to market based solutions with limited government interference. It is interesting that in many respects the IMF was structured by White's plan but developed along the Keynesian view. It is also interesting that contemporary discussions about revising the international financial architecture display the same tension between rule making by intergovernmental agencies and market based solutions.

As noted earlier, adequate provision of liquidity does not solve the inherent flaw of fixed exchange rates, which is the absence of an adjustment mechanism. The BW system dealt with this in two ways. First, there was provision for exchange rate realignments and second, the international financial architecture envisioned at BW reduced the need for liquidity. Specifically, the old BW system assumed that capital controls would remain in place and in fact the IMF articles allowed for the extension of capital controls. Some gradual opening of capital flows was perhaps envisioned but there was clear sense of sequencing - this would not occur until the international financial system could handle the pressures. The solution was admirable but not perfect as noted by Timothy Geithner (2004): “The Fund, from its inceptions was burdened by a mismatch between the aspirations of its architects and the authority and instruments they gave the institution to purse those ambitions.”

How did old BW operate? The post war world envisioned by old BW discouraged capital flows and presumed that current account imbalances would be

\footnotetext{
${ }^{3}$ The approach was not entirely new. In the 1920s and 30s (prior to the collapse of the gold standard), there were League of Nation discussions about how to economize on the use of gold and improve the payments system when 'liquidity' (i.e. gold) was in short supply
} 
quickly corrected with gold reserves and borrowing from the new international organization, the IMF, which would also oversee exchange rate realignments.

The IMF spent a number of years finding its way, accumulating reserves and defining its activities. There were not very many exchange rate realignments and almost a modest amount of IMF lending between the British devaluation in 1948 and the early 1970s. Nevertheless, the world economy got on its feet and trade grew rapidly. What else was going on to provide the grease that kept the engine running? Or, in terms of my taxonomy, how did old BW operate?

The answer lies in the dominant role of the United States. US demand for goods fueled export driven growth in Europe and Japan. Moreover, the dollar became the world's reserve currency. The architects of the BW system did not foresee the role of the dollar. In effect, the old BW system stood on three legs: fixed exchange rates, capital controls and increased liquidity in the form of an increased supply of dollars. ${ }^{4}$

The US ran trade surpluses for some years after the war though they were not large - about 1-2\% of US GDP in the 1950s. By the 1960s the world economy had recovered substantially and the US began to run trade deficits although they were not large relative to US GDP. Unlike the present, US net borrowing from abroad was not large; financing current account deficits was not the source of dollar liquidity to the rest of the world. Unlike the present, large US borrowing was not the source of liquidity to the rest of the world.

In the old BW system, the US acted as a banker or a financial intermediary in the traditional sense of the word. It transformed long term assets into short term liabilities. The source of added liquidity was indeed short term dollar liabilities coming from the US, which were balanced by increases in US holding of long term assets around the world. The US was the world's banker and the dollar was the banking unit of account. ${ }^{5}$ Thus, the third leg of the old BW system was not simply that that the dollar was the source of liquidity. It was that the provision of banking services by the US increased the liquid supply of dollars.

\footnotetext{
${ }^{4}$ This point is particularly interesting because the role of the dollar is the linchpin in discussions of the contemporary international financial system. However, there are significant difference between the role of the dollar in old BW and new BW.

${ }^{5}$ The difference between the provision of banking services by the US in the old BW system and the role of the US as a debtor nation today can not be understated.
} 
However, old BW had its share of problems that ultimately led to its demise. First, exchange rate realignments were needed with increasing frequency. Differences in productivity growth even more than differences in inflation rates led to real exchange rate changes that necessitated changes in parities. Second, as economies matured capital controls began to peel away (sometimes by law, sometimes by practice). Third, the demand for liquidity began to put pressure on the dollar at just the time the US was beginning to run current account deficits.

For some years the system lumbered on because the world's central banks were committed to it and agreed not to call on US gold reserves even when US liabilities exceeded its reserves. However, over time US gold reserves began to dwindle and ultimately President Nixon closed the gold window in 1971. By 1973 the old BW system of fixed exchange rates was a thing of the past. These events can be viewed in two ways. First, it is possible that the end of old BW was a US problem rather than a global liquidity problem. The Viet Nam war inflation put pressure on the dollar and the US did not have enough gold reserves to maintain a fixed exchange rate. Second, we can argue that the old BW system was doomed because it did not allow for enough flexibility of exchange rates. It is possible that a timely realignment of the dollar parity with gold could have kept the system alive.

The old BW operating architecture was the right thing for that time. That odd conference in the mountains of New Hampshire provided a framework for international cooperation, a development institution (the World Bank) and a liquidity facility (IMF loans). The stability of the fixed exchange rate regime in the 1950s and 1960s successfully jump started the world economy.

Contemporary discussions of economic reforms often refer to the idea of sequencing. The absence of proper sequencing can be the death knell of good ideas. ${ }^{6}$ The old BW system, perhaps by accident, got the sequencing right. A closed capital account was the right choice in the immediate post war period. Modern sensibilities bristle at any thought of controlling markets but capital account flexibility had to be put off until the world economy was on better footing. At the same time, and this was not

\footnotetext{
${ }^{6}$ For example, voucher privatization in the Czech Republic was carefully conceived and the right thing to do. But, it failed miserably because legal codes defining ownership, securities laws and bank regulatory authorities were not yet in place. They did not get the sequencing of reforms right.
} 
understood in the 1960s and 1970s, the re-emergence of significant capital market activity implied that the old BW institutions needed to adapt. Fixed exchange rates were a reasonable choice until capital market activity began to overwhelm the availability of both gold and dollar reserves. For five years, from the British devaluation in 1968 to the demise of fixed exchange rates in 1973, policymakers tried to patch up the old BW system.

The old BW system was not altered in any fundamental ways although the IMF's credit creation capabilities were expanded (starting with the creation of Special Drawing Rights in 1969). New lending facilities and expanded quotas increased the fund's capabilities. It also developed the expertise to monitor the world's economies and provide policy advice. The last two decades of the $20^{\text {th }}$ century were defined by international financial crises that the IMF helped ameliorate but could not eliminate. First, in the 1980s, the recycling of petro dollars by international commercial banks resulted in the LDC debt crisis. Second, the 1990s were marked by numerous emerging market banking and exchange rate crises. By the close of the century, there were widespread suggestions that a new international financial architecture was needed.

The new BW structure. The exchange rate crises of the late 1990s gave rise to a vast outpouring of proposals concerning the international financial architecture. The debates were an echo of the Keynes-White disagreements. Should the IMF be a lender of last resort?

For a time, there were suggestions that the IMF's lender of last resort capabilities should be strengthened. A Supplemental Reserve Facility was created in 1997 that gave the fund the ability to provide large amounts of lending for short periods at penalty interest rates. This was very much like the classical idea of a central bank lender of last resort function except that instead of collateral borrowers provided promises regarding future economic policy. The difference between promises and collateral is a large one and it soon became clear that moral hazard might be impossible to avoid in IMF lending.

The lending capabilities of the IMF can be strengthened but "the parallel between the Fund and Bagehot's lender of last resort cannot be taken too far" (Ann Krueger, the IMF First Deputy Managing Director, Nov. 26, 2001). The realization that the fund cannot be a central bank (all countries are too big to fail) muted the search for a new 
international financial architecture. There is no alternative organizational form on the horizon, which would provide a new BW structure that would preclude the reoccurrence of debt or foreign exchange rate crises.

At the same time the IMF has changed and improved its operating capabilities. It plays an important role in crisis prevention by being the source of good information and good advice. It has improved its capabilities in this regard by shifting its emphasis away from macroeconomics and towards data dissemination and financial sector stability. In 1999 the Fund started the Financial Sector Assessment Program (FSAP) to supplement the regular macroeconomic reviews of country policies and performance. These assessments require considerable cooperation on the part of the subject government that can choose to withhold release of the results. ${ }^{7}$ As for crisis resolution, the IMF realized that there is little it can do to force a particular resolution other than provide adjustment loans and use their availability to encourage certain outcomes.

The limits of the IMF's capabilities at resolving crises had been clear much earlier. The sovereign debt problems of the 1980s were worked out gradually through private sector negotiation. Typically, the debts were syndicated bank loans and so the number of holders was fairly small which facilitated a negotiated outcome. The crises of the 1990s were more difficult to manage. Emerging market bonds were widely held which makes a work out process hard to manage. Moreover, the IMF was powerless to force debtors and creditors together.

Thus, the fund proposed a 'Sovereign Debt Restructuring Mechanism,' which would be a sovereign Chapter XI reorganization supervised by the IMF. The fund would have the power to both extend credit and protect debtors. However, any such mechanism would require amendment to the Fund's articles and approval by the US Congress. The political obstacles were formidable and the idea dropped by the wayside by 2003 .

The alternative to an IMF capability for forcing governments to restructure debt was a private sector mechanism. At just the time that the political obstacles to a new Fund sovereign bankruptcy facility became clear, the private sector began to innovate.

\footnotetext{
${ }^{7}$ An internal review by the fund (IMF, January 2006) indicated that the programs need to be strengthened. It suggested that the protocols for stability assessment are not fully developed and that the assessments have not been fully integrated into the Fund's relationship with member countries
} 
Restructuring diffusely held debt is simplified if the bond issues include a collective action clause that keeps holdouts from standing in the way of a negotiated restructuring. The only problem was that the standard bond did not include such clauses and the first introducer would seem to be signaling weakness. Although no one objected to such a clause, no issuer wanted to be the first mover. However, in early 2003, Mexico sold bonds with such a clause (under New York law) and did so without any negative market reaction (see Roubini and Setser, 2004). Such clauses are now common and the calls for an IMF mandate for crisis resolution have receded.

The formal international financial architecture of the new BW system is not profoundly different than the old BW system. However, the environment has changed: closed capital accounts are now the exception rather than the rule, exchange rates are often managed but the overall system is one of market determined exchange rates and both trade and capital market activity has reached the peak levels seen a century ago. The new BW structure does include some new elements. First, the IMF's emphasis on crisis prevention and financial sector stability is a major change in the way it views its mission. Second, the private sector's innovation of collective action clauses along with improved fund lending facilities has improved the system's ability to respond to sovereign financial crises. Finally, exchange rate and financial sector crises have not been occurring with the same frequency as in the 1990s. As a result, the sense of urgency about the structure of the BW institutions has abated.

The tension evinced at the Bretton Wood conference 60 years ago between an international central bank and an international cooperative institution remains in evidence. The IMF of the old BW structure was the latter and the new BW structure is basically the same. It has evolved to respond to a changing environment and continues to works reasonably well.

How does new BW operate? The crises in the 1990s were associated with large current account deficits in emerging market countries. Almost without exception, these countries have become aggressive savers and the most prominent global imbalances are now the large US current account deficits. US borrowing and reserve accumulation by the Asian export economies are the defining characteristics of the new BW. 
It has become fashionable to use the term Bretton Woods system as buzzwords for the way the international financial system is currently operating. In particular, the relationship between the two principal players in world trade - China and the US - is reminiscent of the old BW era. However, there is much disagreement concerning the strength of the analogy.

The analogy was floated by Michael Dooley, David Folkerts-Landau and Peter Garber (DFG) in a series of influential and widely read but unpublished papers beginning in 2003. The elements of the analogy are:

- Although there are no fixed parities at present, for all intents and purposes China's Yuan is fixed to the dollar.

- China maintains a low real exchange rate in order to generate export led growth. Throughout the old BW period, the recovering economies of Japan and Europe had undervalued currencies.

- The dollar serves as the reserve asset and is the source of international liquidity. That was the case under old BW too but there are significant differences in the way capital markets operate.

- The demand for dollar reserves around the world means that US current account deficits can be sustained indefinitely. Similarly, the old BW system was sustained as long as there was confidence in the convertibility of the dollar to gold or to other currencies at fixed or predictable exchange rates. DFG made an interesting, accurate and imaginative observation. There are similarities between old BW (circa 1946-71) and new BW (about the last decade). Their observation was made in 2003 when many observers already expected a reversal of the US current account or at least large dollar depreciation. So, the fact that the current account deficit is larger than it has ever been and that the trade weighted dollar is still fairly strong serve to prove DFG right. There seems to be an analogy between the operations of old and new BW, but there are notable differences as well:

- In old BW, the US had current account surplus and provided liquidity by being the world's banker. It transformed maturities of debt from long term to short term. Pressures on dollar reserves began as soon as deficits emerged, even though they were small. In new BW, the large current account deficits are the source of 
liquidity. The US serves as a banker to the extent that it provides risk free assets, Treasury securities.

- There was widespread support for the way old BW operated. The world's central banks agreed through negotiation to hold US debt and avoid calling on US gold reserves in order to preserve the system. Central bankers at present are unlikely to negotiate a public commitment to continue absorbing US debt. And in any event, such an agreement, as was the case in the late 1960s, only postpones an inevitable adjustment.

- The world financial system is much different in the new BW era: there are extensive capital markets, few capital market restrictions and with the exception of the Yuan/Dollar exchange rate most important exchange rates are floating. Eichengreen (2004) argues forcefully that these differences between the contemporary world economy and the old BW era make the BW analogy a poor one. The dominant position of a reserve currency is maintained by demand and the absence of alternatives. Only the dollar was fixed to gold in old BW and there were no other reserve assets. At the present, capital markets make movement into and out of dollar assets easy and the Euro is standing in the wings. If the world's central banks doubt the Fed's commitment or ability to maintain the value of the dollar, tastes for reserve holding can change quickly, particularly in the absence of capital controls and the liberalization of domestic financial markets in most countries (China being the notable exception).

It took a generation for the gold standard to expire but only five or so years for old BW to die. In the late 1960s policymakers tried to patch together the old BW fixed exchange rate system. Finally, after the US ended gold convertibility in 1971, efforts to hold the fixed exchange rate system together continued for two more years. The new BW era could disappear much more quickly.

Now, if DFG are right and we are now in a new BW era, then the world will continue to absorb US debt as its reserve asset. Indeed the world economy has a strong demand for these assets in order to sustain export growth in China. But, the final lesson from old BW is that all good things come to an end. At some point, the desire to hold more reserves will abate and an adjustment through exchange rate changes and, more likely and potentially more harmful, through changes in demand will occur. Thus, the 
issue at hand is not the strength of the analogy between old and new BW but how the world economy can engineer a soft landing and gradual adjustment.

Richard Cooper (2005) envisions a scenario of gradual adjustments to the supply and demand for dollar reserves that could lead to a soft landing without any dramatic changes in currency values or disruptive movements in interest rates. First, aging populations in Europe and Japan will generate less saving. Second, improved financial intermediation in China will enable domestic saving to meet more of the demand for investment. Third, he predicts that investment rates will level off in China and that the US will reduce its government deficit. Cooper’s paper (“The sustainability...”) contrasts with Nouriel Roubini's (“The unsustainability...”, 2006) view that a sharp adjustment is imminent. He cites numerous cyclical factors that are likely to lead to a weaker dollar. Without weighing one argument against the other, it is interesting to note one similarity. Both papers cited view international policy coordination as the best way to avoid sharp adjustments. However, it is unclear how policy coordination could be initiated. Neither China nor the US is a potential borrower from the IMF that might be influenced by dire warnings in IMF policy reports. The IMF has already done that in its most recent economic reviews of both countries. Economic policy coordination would require political agreement, which has been lacking in the absence of a crisis and with elections looming in many important countries.

The world's political leaders seem to have adopted a view of complacency about international financial imbalances. In contrast, in the waning days of old BW, agreements for coordinated management of reserves kept the system on life support for several years. Later on, there were important episodes of international policy coordination such as the Plaza accords. But, at present there does not seem to be any momentum for cooperation. Moreover, US policymaking and the leadership provided by Ben Bernanke and the White House give short shrift to international adjustments. The reluctance to acknowledge that an adjustment might be due is intentional as if doing so 
will precipitate a crisis. Bernanke's interest in more transparent policy making should include a bolder willingness to address the issues. ${ }^{8}$

Thus, the only sure lesson from old BW for the new BW is that the operating structure will come to an end. Commenting on the old BW system, Eichengreen (1996, p.95) wrote that exchange and capital controls were substitutes for a missing adjustment mechanism, "but their use did not ensure adjustment; it only delayed the day of reckoning." The same can be said for the new BW. The coincidence of China's demand for reserves and the US demand for imports substitutes for an adjustment mechanism and delays but does not preclude a day of reckoning. Thus, there are likely to be tumultuous times ahead for the world's financial system. We also know from the old BW experience that the new BW structure is not entirely equipped to deal with the end of the new BW operating system. It does not have the means or any way of moving economic powers like China and the US away from risky behaviors. Recognizing this requires a degree of economic policy coordination that does not seem to be on anyone’s political agenda.

\footnotetext{
${ }^{8}$ Bernanke's testimony to Congress on July 19, 2006 as part of the semi annual monetary policy report to congress (http://www.federalreserve.gov/boarddocs/hh/2006/july/testimony.htm) makes no mention of external imbalances or exchange rates.
} 


\section{REFERENCES}

Cooper, Richard N. "The sustainability of the US external deficit," CESifo Forum, Spring 2005.

De Vries, Margaret Garritssen. The IMF in a changing world. IMF, Washington, D.C., 1986.

Dooley, Michael, David Folkerts-Landau and Peter Garber. “An essay on the revived Bretton Woods system,” NBER Working Paper 9971, September 2003.

Eichengreen, Barry. Globalizing Capital: A history of the international monetary system. Princeton University Press, 1996.

Eichengreen, Barry. "Global imbalances and the lessons of Bretton Woods," NBER Working Paper 10497, May 2004.

Geithner, Timothy. The Bretton Woods Institutions in the $21^{\text {st }}$ century,” Federal Reserve Bank of NY, June 10, 2004.

International Monetary Fund. "Report on the evaluation of the Financial Sector Assessment Program,” January 2006, http://www.imf.org/external/np/ieo/2006/fsap/eng/index.htm

Krueger, Anne. "International financial architecture for 2002: A new approach to sovereign debt restructuring,” IMF, November 26, 2001.

Roubini, Nouriel. "The unsustainability of the US twin deficits," Cato Journal, (26) Spring/Summer 2006, pp. 343-56.

Roubini, Nouriel and Brad Sester. "The reform of the sovereign debt restructuring process: problems, proposed solutions and the Argentine episode," Journal of Restructuring Finance (1), 2004, 1-12. 